University of Nebraska - Lincoln

DigitalCommons@University of Nebraska - Lincoln

USDA National Wildlife Research Center - Staff Publications
U.S. Department of Agriculture: Animal and Plant Health Inspection Service

2012

\title{
Pond-Level Risk Factors Associated with Columnaris Disease on Mississippi Commercial Catfish Farms
}

\author{
Fred L. Cunningham \\ USDA/APHIS/WS National Wildlife Research Center, fred.I.cunningham@aphis.usda.gov
}

Skip W. Jack

Mississippi State University, jack@cvm.msstate.edu

David Hardin

University of Nebraska-Lincoln, dhardin2@unl.edu

Robert W. Wills

Mississippi State University,wills@cvm.msstate.edu

Follow this and additional works at: https://digitalcommons.unl.edu/icwdm_usdanwrc

Cunningham, Fred L.; Jack, Skip W.; Hardin, David; and Wills, Robert W., "Pond-Level Risk Factors Associated with Columnaris Disease on Mississippi Commercial Catfish Farms" (2012). USDA National Wildlife Research Center - Staff Publications. 1118.

https://digitalcommons.unl.edu/icwdm_usdanwrc/1118

This Article is brought to you for free and open access by the U.S. Department of Agriculture: Animal and Plant Health Inspection Service at DigitalCommons@University of Nebraska - Lincoln. It has been accepted for inclusion in USDA National Wildlife Research Center - Staff Publications by an authorized administrator of DigitalCommons@University of Nebraska - Lincoln. 


\title{
Pond-Level Risk Factors Associated with Columnaris Disease on Mississippi Commercial Catfish Farms
}

\author{
Fred L. Cunningham* \\ Wildlife Services-National Wildlife Research Center, Mississippi Field Station, 125 Stone Boulevard, \\ Scales Building, Mississippi State, Mississippi 39762, USA
}

S. W. Jack

Department of Pathobiology and Population Medicine, College of Veterinary Medicine, Mississippi State University, Post Office Box 6100, Mississippi State, Mississippi 39762, USA

\section{David Hardin}

School of Veterinary Medicine and Biomedical Sciences, University of Nebraska-Lincoln, 120C VBS, Lincoln, Nebraska 68583-0905, USA

\author{
Robert W. Wills \\ Department of Pathobiology and Population Medicine, College of Veterinary Medicine, \\ Mississippi State University, Post Office Box 6100, Mississippi State, Mississippi 39762, USA
}

\begin{abstract}
A large commercial catfish enterprise encompassing over $\mathbf{5 0 0}$ food fish ponds from five farms covering multiple counties in the Mississippi Delta was included in this analysis of columnaris risk factors. A gram-negative bacterium, Flavobacterium columnare, is the cause of columnaris disease and is considered the second-most prevalent bacterial disease in farm-raised catfish. The objective of this study was to determine if pond-level risk factors reported by farm personnel were associated with columnaris disease mortalities. To identify risk factors affecting susceptibility of farm-raised channel catfish Ictalurus punctatus to columnaris disease, a Catfish Management database was developed. Logistic regression was used to model the relationships between probability of columnaris in ponds and risk factors examined. Generalized linear mixed models incorporating hierarchically structured random effects of ponds and one or more fixed-effects risk factors were fitted. In the screening process, each risk factor was evaluated in the basic model as a single fixed-effects factor, and if associated with the outcome $(P \leq 0.20)$, was retained for development of multivariable models. Two multivariable logistic regression models were constructed from data collected at the pond level by producers. The first was constructed from data in which water quality was not considered. Pond depth and reduced feed consumption for a 14-d period prior to disease outbreaks measured on a per hectare basis were significantly $(P \leq 0.05)$ associated with columnaris disease. The second, in which water quality variables were also considered, pond depth, reduced feed consumption, shorter intervals from stocking to disease outbreaks, and total ammonia nitrogen were significantly $(P \leq 0.05)$ associated with columnaris occurrence. This study showed some commonly recorded production variables were associated with columnaris disease outbreaks and, if monitored, could help identify "at risk" ponds before disease outbreaks occur.
\end{abstract}

*Corresponding author: fred.l.cunningham@aphis.usda.gov

Received September 16, 2011; accepted February 9, 2012

Published online August 16, 2012 
A gram-negative bacterium, Flavobacterium columnare, is the cause of columnaris disease, the second most prevalent bacterial disease in farm-raised catfish (USDA/APHIS 2003). Determination of the economic impact of columnaris disease is difficult as it is often part of a mixed infection. Approximately $86 \%$ of the cases from Louisiana involving columnaris were mixed with other bacteria (e.g. Edwardsiella ictaluri, E. tarda and Aeromonas spp.) (Hawke and Thune 1992). Determining which bacteria is primary and which is secondary is very difficult. Columnaris disease was the leading cause of mortality on Mississippi catfish farms in 2000 (Khoo 2001). Over 70\% of the catfish farmers polled considered columnaris disease or mixed infections including columnaris as causing the greatest economic loss on catfish farms in the four leading catfish-producing states (Khoo 2001). Often pond-bank diagnosis of columnaris disease is performed by farm management with confirmation from a diagnostic laboratory.

The bacterium is present in most waters and movement of infected stocks of fish should be minimized to prevent spread of the disease (Wise et al. 2004). Columnaris disease is usually an external infection of the skin, fins, and gills, but F. columnare has been isolated from clinically normal channel catfish Ictalurus punctatus (Hawke and Thune 1992). Catfish at any age, during all seasons, and under a host of water conditions can be infected (Griffin 1987). Columnaris disease is usually transmitted from fish to fish via the water but is usually associated with stressful conditions, such as poor water quality, and fish handling, such as during stocking or harvesting (Hawke and Khoo 2004). Increasing the salinity of water reduces mortality of channel catfish challenged with $F$. columnare (Altinok and Grizzle 2001). Mortality of channel catfish challenged with virulent $F$. columnare is significantly lower at $1 \mathrm{~g} / \mathrm{L}$ salinity than in freshwater, and no mortality occurs at salinities of $3 \mathrm{~g} / \mathrm{L}$ or above (Hawke and Khoo 2004). The bacterium may be less able to bind to gill and skin tissues of the channel catfish at increased levels of salinity (Altinok and Grizzle 2001).

Many agricultural industries use production databases to help improve production. For many years the dairy industry has used the National Dairy Herd Improvement Association (DHIA; Verona, Wisconsin) database. Data collected are used for (1) farm management decisions, (2) educational programs and research, including the genetic evaluation of cows and sires, and (3) promotion and sale of animals. In 2008, over 4.5 million dairy cows were on DHIA programs. The swine industry has used a similar database called PigChamp (Ames, Iowa). Swine producers can track and analyze herd production and benchmark it against other herds. This database has allowed rapid improvement of production through selection of superior animals and allows producers to highlight areas of concern in production. The catfish industry is similar to the swine industry with the key economic drivers: growth rate and feed efficiency. Feed costs are the largest expense in catfish production. Catfish are fed daily as much as they will eat during warm months. Catfish are fed to maximize growth and minimize waste because overfeeding can have a negative effect on water quality. Thus, monitoring feed intake is an important management tool. Some catfish producers use a database, FISHY, developed by the Mississippi State University Agricultural Economics Department (Mississippi State, Mississippi). The FISHY database was designed to help catfish producers improve their production management decision making. This database concentrates on feeding and projecting fish growth. The Catfish Management database developed for this research allows the farm to manage not only feed but also other factors such as stocking, harvesting, and mortality. The Catfish Management database also allows the farm to generate userdefined reports on each pond's efficiency and cost of production.

The objective of this study was to determine pond-level risk factors associated with columnaris disease mortalities. Of particular interest was the determination of production factors reported by farm personnel that could be used to predict the occurrence of disease events.

\section{METHODS}

Sampling and data collection.-A large commercial catfish enterprise agreed to share their production records. Over 500 ponds from five farms dedicated to food fish production and covering multiple counties in the Mississippi Delta were included in this analysis. These ponds had an average size of $5.00 \pm 1.66$ ha (mean $\pm \mathrm{SE}$ ).

To identify risk factors a Catfish Management database was developed. This database was designed to (1) incorporate production data already being recorded for generating reports for use at weekly managerial meetings focused on feeding rates, feed conversion ratios, mortalities, and harvesting events, (2) be easily used by a catfish farmer to collect management data in order to analyze production efficiency through a series of farmer-defined management reports, and (3) provide the farm with easy access to management reports. Additional customized reports were generated as requested by the farm management.

The database was programmed in Microsoft Access (Microsoft, Redmond, Washington). Permanent unique pond identifications (IDs) were assigned to each pond. Data recorded by the producer from 2004 to 2007 were imported into the newly constructed database. Briefly, when a mortality event occurred, the date, pond ID, and reason or cause of the mortality event as well as total weight (pounds), average size, and number of fish lost were recorded. Occasionally affected fish were submitted to the Mississippi State University College of Veterinary Medicine Diagnostic Laboratory located in Stoneville, Mississippi, for laboratory confirmation of columnaris disease.

Pond and production information, later used as explanatory variables in statistical models, were recorded or constructed into four main groups: (1) physical characteristics of the ponds, (2) time interval from fish handling to mortality event, (3) daily feed consumption, and (4) water quality. Physical characteristics of each pond included the surface area (hectares) and average depth (meters) in order to calculate the volume 
(hectare-meter). Surface area was determined from geographical information systems (GIS; ESRI, San Antonio, Texas) files, while pond depth was recorded as a single point measurement supplied by farm management. Disease Pond Age was defined as the age of the pond at the time of a mortality event and was calculated from the time of original construction or from when the pond was rebuilt. A second group of variables included two calculated variables. Disease Stocking Interval was defined as the interval from the time fish were stocked into the pond until a mortality event occurred. Stocking event information was recorded and included the source of the fish stocked, date the pond was stocked, and the number, size, and weight of fish stocked. Disease Harvest Interval was defined as the time from a harvesting event until a mortality event occurred. Harvesting event information was recorded and included the date of the harvest and the weight and number of fish harvested.

The third group of variables dealt with feed consumption. The Catfish Management database contained the feeding records in terms of total kilograms of feed fed for each pond on a daily basis. The total feed fed was then aggregated for periods of $7,14,21$, and $30 \mathrm{~d}$ prior to the columnaris-related mortality event. These values did not take into account the varying sizes of the ponds. In order to compare feed usage the aggregate totals were divided by pond area to calculate feed used per hectare, which was divided by pond depth to calculate feed per meter of depth and divided by pond volume to calculate feed per hectare-meter. These calculations allowed comparisons between ponds of differing sizes, depth, and volumes.

The fourth group of variables involved water quality measurements. A separate water quality database was developed and located in the water quality testing laboratory on the farm. Pond water was tested and values were recorded for total ammonia nitrogen (TAN), nitrites, and chlorides. Chlorides were measured if the TAN level was considered high $(>6 \mathrm{mg} / \mathrm{L})$. The database was designed to automatically generate a report of ponds that exceeded the management-defined ammoniato-nitrite ratio. The water quality database was constructed in 2005 so data from 2005 to 2007 were included in the analysis. Water quality data were collected on a weekly or biweekly basis during the growing season (March-November) and monthly during the nongrowing season.

Statistical procedures: risk factor modeling.-Logistic regression was used to assess the strength of association between the dichotomous outcomes of interest, columnaris occurrence in ponds, and various independent variables that represented potential risk factors for the disease. The data in the study was hierarchically structured, which calls for multilevel modeling (Guo and Zhao 2000) with ponds (level 1) nested in farms (level 2 ), which are nested in the catfish enterprise (level 3). Biases in parameter estimates could result from ignoring observations that are more highly correlated and within clusters or levels. Linear and binary models underestimate standard errors when clustering is not taken into account and the assumption of independence is violated. Multilevel modeling provides more accurate stan- dard errors, confidence intervals, and significance tests by correcting these biases (Guo and Zhao 2000). Generalized linear mixed models designating a binomial distribution with a logitlink function were fitted using the GLIMMIX procedure in SAS 9.2 software for Windows (SAS institute, Cary, North Carolina) to conduct the logistic regression analysis. Random effects were incorporated to account for the repeated measures of ponds and variability among the participating farms and possible intrafarm correlation. In the screening process, each risk factor was evaluated in the basic model as a single fixed-effects factor, and if associated with the outcome $(P \leq 0.20)$ was retained for further analysis. In the second step, all risk factors retained from the screening step were investigated for pairwise collinearity using the CORR procedure in SAS 9.2 software for Windows. Each case of collinearity detected was treated separately.

To build the final multivariable model, the fixed-effects risk factors retained from the screening and collinearity investigations were offered to the basic model all at once as fixed-effects factors. After each model run, the fixed-effects factor with the highest $P$-value was removed until a final model with all the fixed-effects variables significant at $P \leq 0.05$ was developed. Further refinement of the developed full final model was pursued to obtain the most parsimonious model while preserving its explanatory ability. A limited number of tools are available to evaluate the performance of generalized linear mixed models with different sets of predictors for a given outcome. There is no best way to estimate goodness of fit for multilevel models. In nonmultilevel logistic regressions, chi-square goodness-of-fit tests are appropriate when an assumption of independence of observations is met and data are not very sparse (Schukken et al. 2003). These assumptions are not met in multilevel modeling with clustering so the chi-square goodness-of-fit test is not appropriate.

The full model and candidate reduced models were compared using the Akaike Information Criterion (AIC) score. The model that had the smallest AIC score was selected (Burnham and Anderson 2001).

\section{RESULTS}

In columnaris-related mortality events, mean losses were $3,155 \pm 228$ fish (mean $\pm \mathrm{SE}$ ), or $0.53 \pm 0.015 \mathrm{~kg}$ per fish for a total weight loss of $1,612 \pm 127 \mathrm{~kg}$ per mortality event. Columnaris accounted for $18.33 \%$ of the observed mortalities from 2004 to 2007. On a monthly basis, farm-recorded columnaris mortalities peaked in April and again October (Figure 1). Mean pond surface area was $5.1 \pm 0.12$ ha and ranged from 2.0 to 8.9 ha. Mean pond depth was $1.99 \pm 0.028 \mathrm{~m}$ and ranged from 1.1 to $2.7 \mathrm{~m}$. These farms had undergone an aggressive pond rebuilding program from 2005 to 2007 with newer rebuilt ponds being deeper (Figure 2). Mean pond volume was $10.19 \pm$ 0.271 hectare-meters (ha-m) and ranged in volume from 3.16 to 21.91 ha-m. 


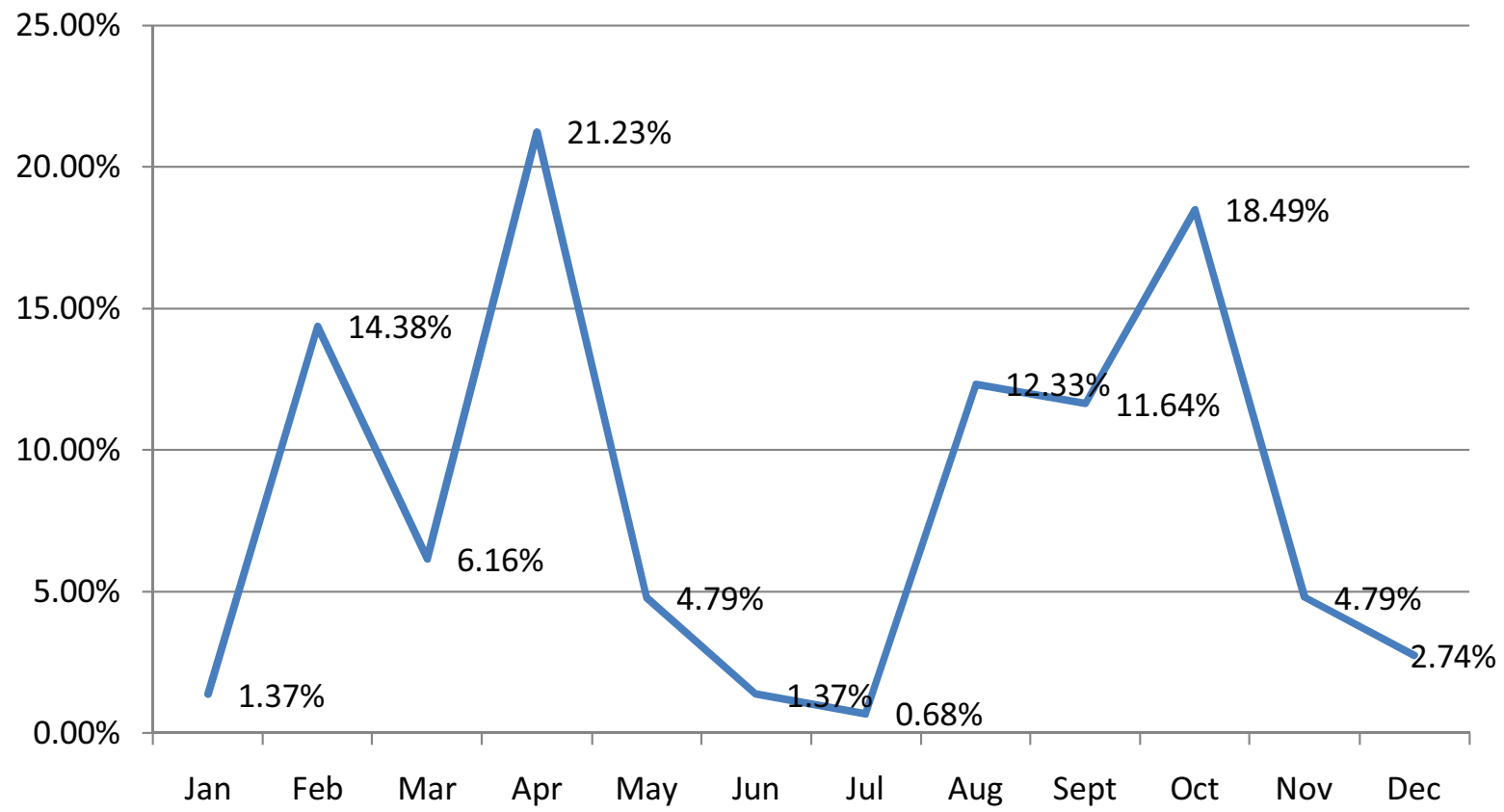

FIGURE 1. Farm-reported percentage of columnaris mortalities (cases per month, 2004-2007). [Figure available in color online.]

The screening process identified 16 variables that had an association $(P \leq 0.2)$ with the occurrence of columnaris and were considered as candidates in a multivariable model (Table 1).

An observation was defined as a pond with a positive mortality event due to columnaris disease as defined by the farm. Ponds without a history of mortality events associated with columnaris were selected as "negative" ponds and served as controls. A negative pond was defined as a pond that did not have a mortality event within the period from $60 \mathrm{~d}$ before to $60 \mathrm{~d}$ after the mortality event date being analyzed. During the variable screening process, it was observed that the number of observations was greatly reduced when water quality variables

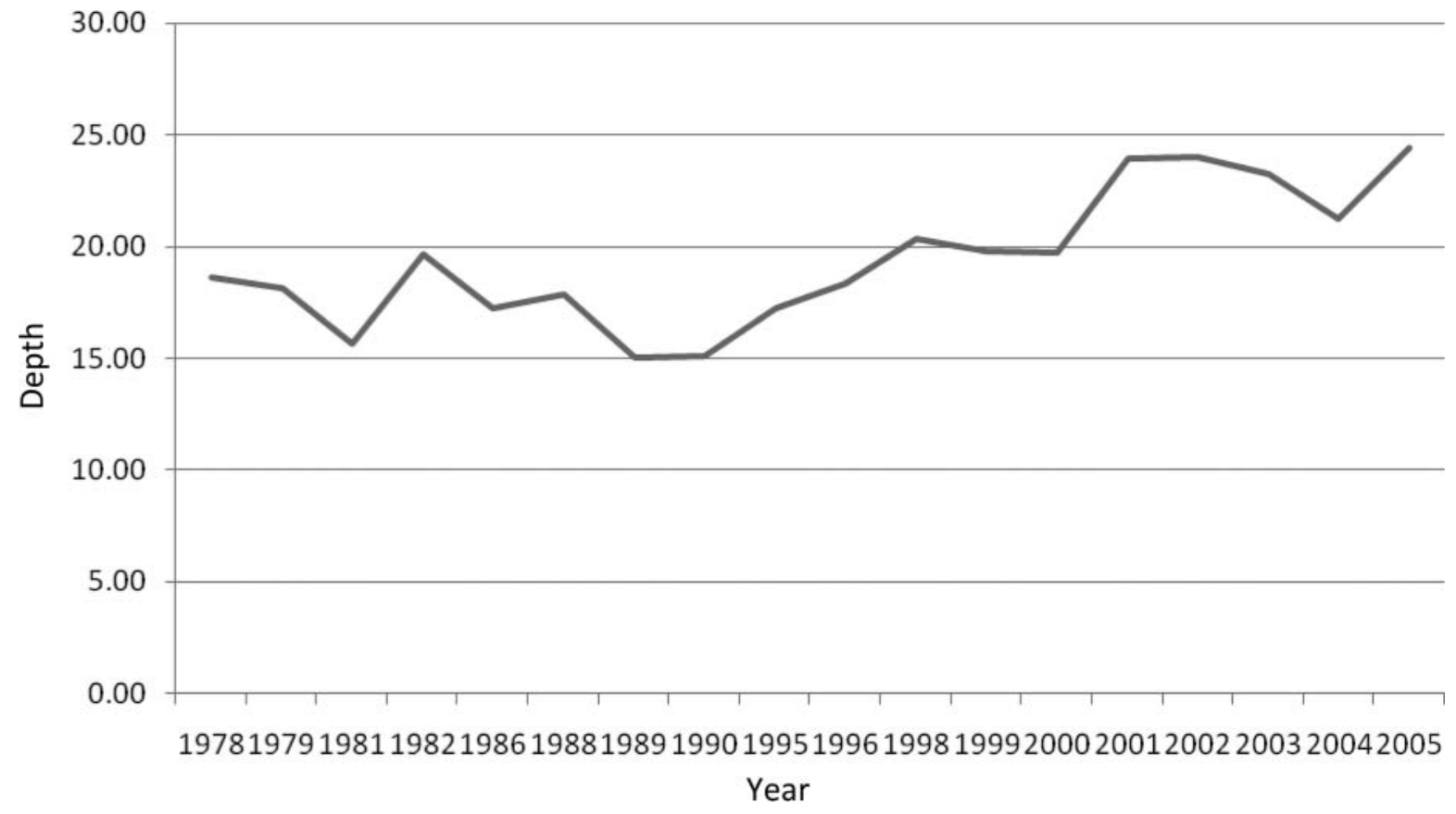

FIGURE 2. Average farm pond depth (dm) by year of construction. 
TABLE 1. Logistic regression results for variables associated with the occurrence of columnaris at catfish farms $(P$-values $<0.20)$.

\begin{tabular}{lccccr}
\hline Variable & Measured unit & $N$ & Odds ratio & Confidence interval & $P$-value \\
\hline Depth & $\mathrm{dm}$ & 10,325 & 1.10 & $1.03-1.18$ & 0.003 \\
Volume & $\mathrm{ha}-\mathrm{m}$ & 10,326 & 1.08 & $1.01-1.14$ & 0.017 \\
Size & $\mathrm{ha}$ & 10,326 & 1.13 & $0.98-1.30$ & 0.103 \\
Disease harvest interval & $30 \mathrm{~d}$ & 10,315 & 1.00 & $1.00-1.00$ & 0.105 \\
Nitrites, 8-14 d & $\mathrm{mg} / \mathrm{L}$ & 3,341 & 0.19 & $0.04-0.93$ & 0.041 \\
Ammonia, 0-7 d & $\mathrm{mg} / \mathrm{L}$ & 3,607 & 1.47 & $1.06-2.03$ & 0.020 \\
Ammonia, 8-14 d & $\mathrm{mg} / \mathrm{L}$ & 3,343 & 1.34 & $1.01-1.79$ & 0.045 \\
Ammonia, 15-21 d & $\mathrm{mg} / \mathrm{L}$ & 2,937 & 2.44 & $1.89-3.15$ & $<0.0001$ \\
Feed, 0-7 d/ha & $\mathrm{kg} / \mathrm{ha}$ & 10,325 & 0.99 & $0.99-1.00$ & 0.076 \\
Feed, 0-14 d/ha & $\mathrm{kg} / \mathrm{ha}$ & 10,325 & 0.95 & $0.99-0.99$ & 0.025 \\
Feed, 0-21 d/ha & $\mathrm{kg} / \mathrm{ha}$ & 10,325 & 0.99 & $0.99-1.00$ & 0.133 \\
Feed, 0-7 d/ha-m & $\mathrm{kg} \cdot \mathrm{ha}^{-1} \cdot \mathrm{m}^{-1}$ & 10,325 & 1.00 & $0.99-1.00$ & 0.039 \\
Feed, 0-14 d/ha-m & $\mathrm{kg} \cdot \mathrm{ha}^{-1} \cdot \mathrm{m}^{1}$ & 10,325 & 1.00 & $0.92-0.99$ & 0.008 \\
Feed, 0-21 d/ha-m & $\mathrm{kg} \cdot \mathrm{ha}^{-1} \cdot \mathrm{m}^{-1}$ & 10,325 & 1.00 & $0.95-1.00$ & 0.045 \\
Feed, 0-30 d/ha-m & $\mathrm{kg} \cdot \mathrm{ha}^{-1} \cdot \mathrm{m}^{-1}$ & 10,325 & 1.00 & $0.97-1.00$ & 0.112 \\
Feed, 0-14 d/m & $\mathrm{kg} / \mathrm{m}$ & 10,325 & 1.00 & $0.99-1.00$ & 0.111 \\
\hline
\end{tabular}

were considered. This occurred because of the water quality database not being constructed until 2005 and the sampling frequency of the ponds. Consequently, two separate multivariable models were developed. The first analysis excluded water quality variables, which resulted in 10,711 potential observations. In the second analysis, water quality variables were included reducing the number of observations to 3,950.

In the analysis that excluded water quality variables, the most parsimonious multivariable model included two effects in the final model: depth of the pond and feed fed for $14 \mathrm{~d}$, on a per hectare basis, prior to the disease outbreaks (Table 2). As pond depth increased the odds of a mortality event associated with columnaris occurring in a pond increased. For each $100-\mathrm{kg} / \mathrm{ha}$ increase in feed fed $14 \mathrm{~d}$ prior to a disease outbreak the odds of a mortality event associated with columnaris occurring in a pond decreased. For the ponds included in the analysis that excluded water quality variables, the mean pond surface area was $4.7 \pm$ 0.02 ha and mean pond depth was $18.3 \pm 0.04$ decimeters $(\mathrm{dm})$.

For the analysis that included water quality variables, the most parsimonious multivariable model included four effects in the final model: depth of the pond, feed fed for $14 \mathrm{~d}$ prior to the disease breaks on a per hectare basis, TAN measured within $7 \mathrm{~d}$ of a mortality event, and the interval from stocking

TABLE 2. Model excluding water quality variables.

\begin{tabular}{lllr}
\hline Variables & $\begin{array}{c}\text { Odds } \\
\text { ratio }\end{array}$ & $\begin{array}{c}\text { Confidence } \\
\text { interval }\end{array}$ & $P$-value \\
\hline Pond depth $(\mathrm{dm})$ & 1.1 & $1.03-1.18$ & 0.003 \\
$\begin{array}{l}\text { Feed }(100 \mathrm{~kg} / \mathrm{ha}), 14 \mathrm{~d} \\
\text { prior to disease }\end{array}$ & 0.99 & $0.991-0.999$ & 0.025 \\
\hline
\end{tabular}

of new fish to a mortality event (Table 3). As pond depth and TAN increased, the odds of a mortality event associated with columnaris occurring in a pond increased. For each $100-\mathrm{kg} / \mathrm{ha}$ increase in feed fed $14 \mathrm{~d}$ prior to a disease outbreak and the longer the interval from stocking of new fish in a pond until a mortality event, the odds of a mortality event associated with columnaris occurring in a pond was decreased. The mean time from a stocking to a mortality event during 30-d time periods was $16.6 \pm 0.13 \mathrm{~d}$. For the ponds included in the analysis that included water quality variables, mean pond surface area was $4.8 \pm 0.03$ ha and mean pond depth was $18.5 \pm 0.06 \mathrm{dm}$.

\section{DISCUSSION}

The objective of this study was to identify potential risk factors associated with mortality events that the farm managers attributed to columnaris disease. Pond depth was significantly associated with columnaris occurrence in analyses that both included and excluded water quality variables. Pond-depth

TABLE 3. Model including water quality variables.

\begin{tabular}{|c|c|c|c|}
\hline Variables & $\begin{array}{l}\text { Odds } \\
\text { ratio }\end{array}$ & $\begin{array}{l}\text { Confidence } \\
\text { interval }\end{array}$ & $P$-value \\
\hline Pond depth (dm) & 1.2 & $1.10-1.34$ & 0.0001 \\
\hline $\begin{array}{l}\text { Feed }(100 \mathrm{~kg} / \mathrm{ha}), 14 \mathrm{~d} \text { prior } \\
\text { to disease }\end{array}$ & 0.97 & $0.967-0.979$ & $<0.0001$ \\
\hline $\begin{array}{l}\text { Total ammonia nitrogen } \\
\text { (TAN; mg/L), } 7 \mathrm{~d} \text { prior to } \\
\text { disease }\end{array}$ & 1.77 & $1.26-2.48$ & 0.0009 \\
\hline $\begin{array}{l}\text { Stocking to disease time } \\
\text { interval }(30 \mathrm{~d})\end{array}$ & 0.41 & $0.25-0.66$ & 0.0003 \\
\hline
\end{tabular}


data were a single measurement reported by the farm. Catfish ponds are sloped and are shallower at the margins and often on one end, and deeper on the opposite end. Pond depth can be influenced by the age of the pond and sediment accumulation. Mean sediment depth increased with pond age, although the rate of sediment accumulation was greatest in the first year $(12.5 \mathrm{~cm} /$ year) (Steeby et al. 2004). Rebuilt ponds are deeper on these farms (Figure 2). A survey of catfish farmers found that the average pond depth in the southern region, including Alabama, Arkansas, Louisiana, and Mississippi, was $5.5 \mathrm{ft}$ or $1.67 \mathrm{~m}(N=$ 553) (Hanson et al. 2008). Mississippi Agriculture and Forestry Experiment Station researchers recommended that catfish ponds should have an average depth of 6-7 ft or 1.83-2.13 m (Coblentz 2003). Increased pond depth reduced nonspecific disease-related catfish losses (Hanson et al. 2008). In contrast this study found greater pond depth increased the odds of a mortality event associated with columnaris disease. Deeper ponds have a greater volume. Since aeration is based on pond size and not volume, deeper ponds may have reduced aeration levels and lower oxygen content leading to greater stress in the fish. This stress may lead to increased odds of a columanaris-related mortality event. We may also find that the odds of a mortality event related to pond depth differ with individual catfish diseases.

Reduced feed consumption for a 14-d period measured on a per hectare basis was significantly associated with columnaris occurrence in the analysis of both of these models. It is not surprising that fish in the ponds would have reduced feed consumption before a disease outbreak. Past studies have found that sick fish have reduced feed consumption (Robinson et al. 2004). This study suggests that monitoring feed consumption in ponds using a 14-d rolling average would offer a way to identify ponds that have a higher risk of mortality associated with columnaris disease. These ponds could then be targeted for closer scrutiny to determine the status of the pond.

The analysis that included water quality data indicated that these variables appear to be important, but limited data make interpretation difficult. Water quality data were limited because of the lack of recorded values before 2005 and to the sampling frequency of the ponds. Intermittent frequency of testing during the growing and nongrowing seasons resulted in missing data. Water quality data, if available, were recorded $0-7,8-14$, and $15-21 \mathrm{~d}$ prior to each mortality event date, but only the $0-7-\mathrm{d}$ period for TAN remained in the model.

Elevated ammonia levels can cause physiological, biochemical, histological, and behavioral effects in fish (Hargreaves and Tomasso 2004). In channel catfish ammonia is carried in the blood and excreted as un-ionized ammonia $\left(\mathrm{NH}_{3}\right)$. Total ammonia nitrogen $\left(\mathrm{NH}_{3}+\mathrm{NH}_{4}{ }^{+}\right)$is partitioned between ionized and un-ionized forms depending on environmental $\mathrm{pH}$ and temperature. The diffusion of $\mathrm{NH}_{3}$ across the gill epithelium is a function of water $\mathrm{pH}$, plasma $\mathrm{pH}$, and total ammonia concentration (Hargreaves and Tomasso 2004). Low dissolved oxygen levels can increase the effect of high ammonia levels.
In commercial catfish ponds, ammonia rarely accumulates to concentrations that cause death; ammonia is much more likely to have sublethal effects that reduce growth or compromise immunocompetence, and even low levels of total ammonia $(0.43 \mathrm{mg} / \mathrm{L})$ can reduce voluntary feed consumption by $68 \%$ (Hargreaves and Tomasso 2004). In this study, ponds that had higher ammonia levels had increased odds of experiencing a columnaris-associated mortality event. These higher ammonia levels may have led to reduced immunocompetence and feed consumption, which may have contributed to a columnaris disease mortality event. Elevated ammonia levels were observed within $7 \mathrm{~d}$ before the mortality event and could serve as an indicator that the pond should be carefully monitored.

Shorter intervals from stocking to occurrence of disease were significantly associated with ponds that experienced a columnaris mortality event. These shorter intervals could have been due to the introduction of naive fish into a pond with infected fish. Fingerlings, especially in their first fall, are susceptible to columnaris even without predisposing stress factors (Wise et al. 2004). Introducing infected fish into a pond with a population of naïve fish may also cause columnaris disease. The bacterium is considered ubiquitous in most waters, but movement of infected stocks of fish should be minimized to prevent spread of the disease (Wise et al. 2004). Stress resulting from poor water quality or handling of fish, such as during stocking and harvesting, can play a part in a columnaris disease outbreak (Hawke and Khoo 2004).

There are limitations to these data sets. These data were used in the management of the catfish farm and assumed to be accurate. Compared with a prospective study, a disadvantage of this retrospective study was that key variables such as dissolved oxygen levels and $\mathrm{pH}$ of the pond were not recorded. The variables described in this study are associated with columnaris mortality events but do not necessarily cause columnaris disease. They are, however, good variables to consider when designing controlled experiments to determine which farm-level risk factors actually cause columnaris-associated mortalities. The model and methodology developed for this study may well be useful for the investigation of additional economically important catfish diseases. This study showed that some commonly recorded production variables (feed consumption, pond depth, ammonia levels, and stocking events) were associated with columnaris disease outbreaks and, if monitored, could help identify "at risk" ponds prior to disease outbreaks.

\section{ACKNOWLEDGMENTS}

Richard Randle, Al Camus, and Terry Hanson are thanked for their support of this project. Mention of trade names or commercial products is solely for the purpose of providing specific information and does not imply recommendation or endorsement by the U.S. Department of Agriculture. 


\section{REFERENCES}

Altinok, I. A., and J. M. Grizzle. 2001. Effects of low salinities on Flavobacterium columnare infection of euryhaline and freshwater stenohaline fish. Journal of Fish Diseases 24:361-367.

Burnham, K., and D. Anderson. 2001. Kullback-Leibler information as a basis for strong inference in ecological studies. Wildlife Research 28:111-119.

Coblentz, B. 2003. Research shows promise of deeper catfish ponds. Mississippi Agriculture and Forestry Experiment Station Research Highlights (Fall): $14-15$.

Griffin, B. R. 1987. Columnaris disease: recent advances in research. Aquaculture Magazine 13:48-50.

Guo, G., and H. Zhao. 2000. Multilevel modeling for binary data. Annual Review of Sociology 26:441-462.

Hanson, T., S. Shaik, K. Coble, S. Edwards, and J. Miller. 2008. Identifying risk factors affecting weather and disease related losses in the U.S. farm raised catfish industry. Agriculture and Resource Economic Review 37:27-40.

Hargreaves, J., and J. R. Tomasso. 2004. Environmental biology. Pages 36-63 in J. A. Hargreaves and C. S. Tucker, editors. Biology and culture of channel catfish. Elsevier, Amsterdam.

Hawke, J. P., and L. H. Khoo. 2004. Health management. Pages 387-443 in J. A. Hargreaves and C. S. Tucker, editors. Biology and culture of channel catfish. Elsevier, Amsterdam.
Hawke, J. P., and R. L. Thune. 1992. Systemic isolation and antimicrobic susceptibility of Cytophaga columnaris from commercially reared channel catfish. Journal of Aquatic Animal Health 4:109-113.

Khoo, L. H. 2001. Annual fish diagnostic laboratory report for 2000. NWAC News: Thad Cochran National Warmwater Aquaculture Center (July): 6-7.

Robinson, E. H., B. B. Manning, and L. H. Menghe. 2004. Feeds and feeding practices. Pages 324-347 in J. A. Hargreaves and C. S. Tucker, editors. Biology and culture of channel catfish. Elsevier, Amsterdam.

Steeby, J. A., J. Hargreaves, C. S. Tucker, and S. Kingsbury. 2004. Accumulation, organic carbon and dry matter concentration of sediment in commercial channel catfish ponds. Aquaculture Engineering 30:115-126.

Schukken, Y. H., Y. T. Grohn, B. McDermott, and J. J. McDermott. 2003. Analysis of correlated discrete observations: background, examples and solutions. Preventive Veterinary Medicine 59:223-240.

USDA/APHIS (U.S. Department of Agriculture/Animal Plant Health Inspection Service). 2003. Catfish 2003 part II: reference of foodfish catfish health production practices in the United States, 2003. USDA/APHIS, Fort Collins, Colorado.

Wise, D., A. Camus, T. Schwedler, and J. Terhune. 2004. Infectious diseases. Pages 444-502 in J. A. Hargreaves and C. S. Tucker, editors. Biology and culture of channel catfish. Elsevier, Amsterdam. 